University of Wollongong

Research Online

Faculty of Business - Papers (Archive)

Faculty of Business and Law

$1-1-2014$

Ideology diffusion and the role of accounting: a Gramscian approach to understanding China's transition from 1949 to 1957

Lina Xu

University of Wollongong, Ix992@uowmail.edu.au

Corinne Cortese

University of Wollongong, corinne@uow.edu.au

Eagle Zhang

University of Sydney

Follow this and additional works at: https://ro.uow.edu.au/buspapers

Part of the Business Commons

Research Online is the open access institutional repository for the University of Wollongong. For further information contact the UOW Library: research-pubs@uow.edu.au 


\title{
Ideology diffusion and the role of accounting: a Gramscian approach to understanding China's transition from 1949 to 1957
}

\begin{abstract}
Using Gramsci's concept of hegemony, the aim of this article is to explore the role of ideology diffusion in creating and maintaining Mao's political hegemony during the period 1949 to 1957, and to consider how accounting practices were reflected in this period of transition in China. In particular, we provide an understanding of how accounting systems have changed under the influence of various political ideologies in China, being the New Democracy and the socialist ideology adopted from the Soviet Union, by considering the relationships and struggles between organic and traditional intellectuals that Gramsci has theorized. We find that the diffusion of political ideologies is reflected in the accounting systems used in these particular periods of transition.
\end{abstract}

\section{Keywords}

accounting, gramscian, approach, transition, role, 1949, 1957, china, ideology, understanding, diffusion

Disciplines

Business

\section{Publication Details}

Xu, L., Cortese, C. \& Zhang, E. (2014). Ideology diffusion and the role of accounting: a Gramscian approach to understanding China's transition from 1949 to 1957. Accounting History, 19 (4), 434-451. 
Paper \#: 04/13

\section{Ideology diffusion and the role of accounting: A Gramscian approach to understanding China's transition from 1949 to 1957}

Lina $\mathrm{Xu}^{1}$, Corinne Cortese ${ }^{1}$ and Eagle Zhang ${ }^{2}$

\footnotetext{
${ }^{1}$ School of Accounting, Economics and Finance, University of Wollongong, Australia

${ }^{2}$ Discipline of Accounting, University of Sydney, Australia

Corresponding author:

Corinne Cortese, School of Accounting \& Finance, University of Wollongong, Northfields Avenue, Wollongong, NSW, 2500, Australia. Email: corinne@uow.edu.au
} 


\begin{abstract}
The aim of this paper is to explore the role of ideology diffusion in creating and maintaining Mao’s political hegemony during the period 1949 to 1957, and consider how accounting practices were reflected in this period of transition in China. This paper uses Gramsci's concept of hegemony to investigate Chinese accounting systems in the period of transition from 1949 to 1957. In particular, we provide an understanding of how accounting systems have changed under the influence of various political ideologies in China, being the New Democracy and the socialist ideology adopted from the Soviet Union by considering the relationships and struggles between organic and traditional intellectuals that Gramsci has theorized. We find that the diffusion of political ideologies is reflected in the accounting systems used in these particular periods of transition.
\end{abstract}

\title{
Keywords
}

Gramsci, ideologies, China, accounting systems, Mao’s hegemony 


\section{Introduction}

Over the last several decades, a substantial number of accounting studies have adopted alternative theoretical lenses to study phenomena, such as, the relationships between the state and the accounting profession (e.g. Chua and Poullaos, 1993, 1998; Sikka, 1995; Sikka and Dunn, 1998); the nature and use of accounting systems (e.g. Funnell, 1998; Llewellyn and Northcott, 2005, Josiah et al., 2010; Zhang and Andrew, 2010); and the intrinsic link between accounting and power (e.g. Sikka and Willmott 1995; Cortese, 2011; Moerman and Van der, 2007; O’Dwyer, 2005). Many of these studies argue that accounting is a technology capable of privileging particular social classes, and perpetuating positions of dominance and power. However, these research studies have focussed primarily on western contexts and alternative examinations of the role of accounting have not been widely conducted in Asian countries such as China. To contribute to this literature, this paper examines the role of accounting during the period 1949 to 1957 in China and argues that accounting practices reflected, and were reflected in, struggles for power during this period of transition under the Maoist regime.

In extant studies of accounting history in China, two distinct time periods have been used because each represents a clear distinction between China's economic policies. The first, from 1949 to 1978, comprises the time from Mao's establishment of the 
People’s Republic of China in 1949 to the beginning of China's ongoing economic reform in 1978. The second period, from 1978 onwards, represents the emergence of contemporary China initiated by Deng Xiaoping, who led China following the death of Mao in 1976. Although these distinct socio-political time periods provide a useful dichotomy for studies of China's progress, they do not fully reflect the controversies and complications that arose within each discrete period. For example, within the Maoist period, although the communist ideology dominated, there were different stages within this period that reflected competing social and political priorities of the time, such as the New Democracy (1949-1953), the Great Leap Forward (1958-1960), and the Cultural Revolution (1966-1976). ${ }^{1}$

We have selected the period 1949 to 1957 as the period of study because this stage within the Maoist period differs significantly in terms of political stability and economic strategies manifesting in China at the time. This stage was a time of critical transition during which the Chinese Communist Party (CCP) established a strong and centralised system with impressive economic growth after decades of social fragmentation and civil war (Twitchett and Fairbank, 1991). Compared to later stages in the Maoist regime, such as the Anti-Rightist movement that began in $1957^{2}$ and the Cultural Revolution from 1966 to 1976, this was a remarkable period in which China maintained minimal divisions and conflicts among party elites, and exceptionally smooth economic progress 
(Fairbank and Feuerweker, 1986). ${ }^{3}$ This stage offers a unique context for the study of Chinese accounting practices during the Maoist regime which has not been fully addressed in the accounting literature.

To contribute to our understanding of Chinese accounting history during the period 1949 to 1957, this paper adopts a Gramscian approach to examine the diffusion of political ideology and the role of accounting in this diffusion process. The Gramscian lens is beneficial because it expressly considers the political and cultural factors that influence the process of ideology diffusion. This is considered as an alternative approach that overcomes the over-reliance on economism of classical Marxist theory in studying social change (Richardson, 1987; Simon, 1982).

The data used in this paper is archival, and was obtained from several sources. Official government regulations were gathered to provide support for the existence of particular forms of accounting during the period of study. The top Chinese accounting journals that were published during 1949 to 1957, namely New Accounting and Industry Accounting are examined to understand how accounting was viewed and articulated by academics and professionals during this period. ${ }^{4}$ Chinese accounting textbooks that were used in tertiary education from 1949 to 1957, published by Lixin Accounting Publishing House, ${ }^{5}$ were also obtained. Finally, data was gathered from academic 
literature in which Western and Chinese scholars discuss the development of China. The data from Chinese sources was translated by the authors.

The remainder of this paper is organised as follows: section two introduces Gramsci's theory of hegemony; section three describes a brief history of the Chinese accounting system prior 1949 to provide background information; section four analyses empirical evidence to demonstrate how certain political ideologies were diffused and how this process influenced accounting systems during the period 1949 to 1957; section five summarises the main findings for this paper.

\section{Gramsci's theory of hegemony}

Antonio Gramsci (1891-1937) was an important figure in Italian communist history as the founding member and one time leader of the Italian Socialist Party (Bates, 1975). After his arrest and imprisonment at the hands of the Fascist regime in 1926, Gramsci wrote his "Prison Notebooks" ${ }^{6}$ which traced his views on Italian history, nationalism, Marxist theory, and critical theory (Bates, 1975). Throughout the Notebooks, Gramsci attempted to identify relationships between political control, economic crisis, and civil society by revising classical understandings of the Marxist role of the state in society (Femia, 1975). A common interpretation of Marxism argues that economic 
developments, or productive forces, are the fundamental drivers of socio-political development (Simon, 1982). It is within the economic base that political changes and struggles are argued to occur. Marxist ideas view economic crises and economic collapse as inherent in capitalism, arising as a result of conflict between economic and productive forces (Simon, 1982). Gramsci suggested that this view assumes the existence of a passive labour force that waits for and expects an inevitable economic crisis in order to spark change in the power relations within capitalist systems (Simon, 1982). Gramsci argued that, instead, the foundation for social transformation comes from political initiatives that shift the balance of class power to achieve hegemony (Simon, 1982).

According to Gramsci (1971), hegemony should be achieved through a combination of coercion and intellectual and moral leadership. He argued that while the capture of state power can be achieved via coercive force, an effective maintenance of power lies in the capacity of ruling party to continuously balance the interests of diverse social forces. This requires constant (re)negotiation among various class interests in the shifting socio-political relations and may involve many social movements that are dependent on the interests of a variety of stakeholders, and not necessarily the productive forces alone. Central to this process is the development of a collective consciousness in order that a political alliance be established and maintained (Simon, 1982). Hence, Gramsci’s theory 
considers the construction of hegemony to be a dynamic process, in which various social classes mobilise and combine to form a system of alliances that diffuses and popularises the world view of the ruling class (Bates, 1975: 352; Simon, 1982). This view is argued to advance the work of proletariat by re-focusing attention on ideology construction, rather than the production process, during power struggles. This is illustrated by Richardson (1987: 350) when he summarised the main differences between the Marxist and Gramscian approaches:

"First, Gramsci rejects the definition of class based on the individual's position in the productive process. Second, hegemony was regarded [by Gramsci] as a material aspect of society and not a "superstructure" to be derived from economic relations. Third, Gramsci asserted that hegemony was used by all ruling classes including the proletariat. He, thus, called on the proletariat to undermine the hegemony of capitalist interests and establish a working class hegemony rather than focussing on control of the labour process.”

Gramsci (1971) introduced two types of intellectuals that he perceived as agents of ideological practice in the construction of hegemony. Gramsci (1971) defined these intellectuals generally as those who were credited with the authority to speak over general philosophical, social and ethical matters, given their perceived expertise of reason and truth. These intellectuals, categorised as traditional and organic, were 
considered the essential players that assisted in educating people towards the development of a common conception of the social structure. In other words, Gramsci (1971) considered that these traditional and organic intellectuals played a central role in diffusing ideologies among various class interests during the process of hegemonic construction (Gramsci, 1971).

Gramsci (1971) theorised traditional intellectuals to be an independent social group that maintains its hegemonic commitment to an existing social order, whereas the organic intellectuals behave as a dynamic force and are active in times of socio-political transition, supporting and promoting new hegemonic orders. Gramsci (1971) viewed traditional intellectuals as affixed to the institutions of the previous hegemonic order, whilst organic intellectuals sought to counter the former (traditional) hegemonic ideas. Gramsci emphasised the importance of organic intellectuals by describing them as "elite" agents of moral and intellectual reforms because of their role in transferring the necessary political consciousness to the working class so that hegemonic leadership could be obtained (Simon, 1982: 99).

The development of a group of organic intellectuals that can influence the interests of the working class, according to Gramsci, is the most common yet complicated issue in any social transformation in a class society. The struggle to win over, or absorb, the 
traditional intellectuals, in the moral and academic sense so that they take on the views of the organic intellectuals, is essential if the ruling class is to maintain political hegemony (Gramsci, 1971). This process of struggle between traditional and organic intellectuals in spreading different political ideas, as section 4 shows, was particularly apparent during the transitional stage of China’s history that this paper studies.

A valuable insight offered by Gramsci's theory to studies of accounting is its accommodation of the relationship between power and ideology, and the role of the state in shaping accounting practices. Richardson (1989) adopted Gramsci’s conception of hegemony to examine the role of accounting as a legitimating institution at both organisational and social levels. In his 1989 paper, Richardson (1989: 423) argued that Chartered Accountants used their “moral and intellectual leadership (i.e. hegemony)” in an attempt to manufacture dominance over the accounting profession in Ontario, Canada. Other studies have used Gramsci's theory to explore the role of accounting in constituting and reflecting ideologies of the state (Cooper, 1995; Goddard, 2002), and the changing roles of accounting within evolving hegemonic climates (Lehman and Tinker, 1987, Goddard, 2002, 2005; Alawattage and Wickramasinghe, 2008; Spence, 2009). 
Studies of China, as an important example of an authoritarian nation, can also benefit from analyses based on Gramsci’s theory of hegemony (Sim, 2006). Many studies have adopted this theory to offer valuable insights in other authoritarian countries in the field of social science, such as Singapore (Sim, 2006), Cambodia (Landau, 2008), Vietnam (Landau, 2008), and Malaysia (Miles and Croucher, 2013). These papers have recognised Gramscian theory as a useful approach for the study of power struggles in these Asian countries. Sim (2006: 145) noted the importance of research that considers the role of ideology in authoritarian countries, and remarked on its absense from much of literature:

“...it is either ignored (by focusing on coercion), dismissed as an excuse for coercion, as ineffective, or dismissed as false when it is deemed effective ... there is no ability to see ideology as a part of everyday governance in all societies ... we have to accept that ideologically successful authoritarian governments can secure as much legitimacy as democratic government.”

To contribute to the literature in this area, Gramsci's idea of hegemony allows us to theorise the power dynamics at the institutional level, while also highlighting the political role of accounting. It has been argued that accounting, like many other professions, attempts to obtain acknowledgement in its community by spreading the 
powers and privileges that come with professional knowledge (West, 1996; Sikka, 2004). West and Carnegie (2010: 203) noted:

“Organisations that formally adopt practices and procedures that are institutionalised in society increase their legitimacy as a result and, accordingly, enhance their prospects of survival. Accounting practices, among other technical practices, become taken-for-granted means to accomplish organisational ends and, as the techniques become institutionalised in specific contents, they establish an organisation as appropriate, rational, and modern”.

The political role of accounting as a form of social knowledge has been recognised in many notable studies (e.g. Andrew and Cortese, 2013; Zhang et al., 2012; Ferguson et al., 2009; Rodrigues and Craig, 2009; Evans, 2010; Yee, 2009; Merino et al. 2010; Ji and Lu, 2013). Understanding this role of accounting in a Chinese context also presents a emerging area of interest. Studies that investigate the different socio-economic contexts of China prior to the 1978 economic reform are few (e.g. Ezzamel et al., 2007; Graham and Li, 1997; Chen, 1998). Further, post-1978 research focuses on the technical aspects of accounting practice with considerable attention directed to the implementation of Western accounting standards in China (e.g. Winkle et al., 1994; Tang, 1997; Bing, 1998; Chan and Rotenberg, 1999; Lin and Chen, 2000; Tang and Lau, 2000; You and Luo, 2009). Only a few studies have addressed the impact of political 
and cultural ideologies on accounting systems in China from this critical perspective. These include studies by Ezzamel et al., (2007) and Yee (2009, 2012).

Ezzamel et al. (2007) examined accounting change under Maoist and Dengist periods in China, demonstrating how accounting discourses are fundamentally shaped by different political ideologies. Yee (2009) used Gramsci’s theory of hegemony to examine the political circumstances that led to the re-emergence of the accounting profession at the beginning of the 1980s in China. This paper contributes to these research studies by providing further evidence of the impact of political and cultural ideology on Chinese accounting systems, going further back in time to examine how new ideologies were established and the implications for accounting systems during the transitional period 1949 to 1957.

\section{A brief history of accounting systems in China prior to 1949}

Accounting has a long history in China. Bookkeeping methods can be traced back to the Shang Dynasty (1500 to 1000 B.C.), during which accounting was used to record the increasing wealth of the royal family (Chen, 1998). However, the earliest record of the word “accounting” emerged in Mencius’ book, The Rites of Zhou (circa 770-475 B.C.) (Lu and Aiken, 2003). With the development of commercial and economic activities in 
ancient China, single bookkeeping methods, such as "Four-pillar balancing”, “Longmen Zhang”, and "Shou-fu bookkeeping” (Chen, 1998; Lin, 2003) were not sufficient for government and private-sector record-keeping (Chen, 1998). These emerged during the fifteenth century and focussed on recording transactions on the basis of receipts and payments (Chen, 1998; Gao and Handley-Schachler, 2003; Solas and Ayhan, 2007). These methods, however, existed primarily to serve the needs of the government sector, and accounting practice in the commercial and non-government sectors was largely under-developed (Fu, 1971; Aiken and Lu, 1993).

Following the Opium War in 1840, China became a semi-colonial and semi-feudal society for the first time (Meisner, 1999). Change occurred in all aspects of society which significantly enhanced the scale and sophistication of economic activities (Aiken and Lu, 1993). The western double-entry bookkeeping method was introduced into China during that period, and became popular throughout large and medium-size firms operating across the country (Lin, 2003; Aiken and Lu, 1993). The first book, Interlocking Bookkeeping, was written and published in China in 1905 by one accounting scholar, Xi Yongcai, and attempted to reconcile the differences between Chinese traditional accounting methods and Western accounting systems (Chen, 1998). During this early period, and up to the time of the establishment of the People's Republic in 1949, accounting textbooks used in China were either translated American 
accounting textbooks or original American accounting books. The accounting systems adopted up to 1949 were significantly influenced by western accounting systems (Ge and Liu, 1999). However, after the CCP took over power in 1949, socialism was officially adopted as the ultimate goal for Chinese society and, as a result, anti-western and anti-capitalist sentiments were dominant in the political environment (Ge and Liu, 1999). This transitional period (1949-1957) presents a unique context for study of the

reconfiguration of dominant political and socio-economic norms and the role accounting played during this process (Chen, 1998).

\section{Empirical analysis}

In this study, empirical research data from the period 1949 to 1957 is analysed from a hegemonic perspective. In doing so, two major ideological movements are identified during this period - New Democracy and Leaning to One Side. The role of accounting intellectuals in the diffusion of these political ideologies are made visible by revealing how accounting practices shifted to reflect and facilitate the changing ideological positions of China.

\section{New Democracy}


The ideological foundation for consolidating the political power of the CCP during the initial transitional period of China was based on a concept of "New Democracy" developed by Mao Zedong in 1940. It was described as a “democratic dictatorship” and was to be a network of alliances of workers, peasants, petty bourgeoisie and national bourgeoisie led by the proletariat and the CCP (Grasso et al., 2004: 145). This was different to the "dictatorship of the proletariat" that prevailed in the Soviet Union where the bourgeoisie were treated as a class enemy (Grasso et al., 2004: 145). Under Mao’s idea of the New Democracy, some of the bourgeoisie would be incorporated into the productive forces, but the proletariat and the communist party would maintain leadership and dominate any reactionary elements of the new regime (Grasso et al., 2004).

The ideological system of the New Democracy saw the establishment of a "centralized state and national market, the assertion of national economic interests, the curbing of pre-capitalist rural elites, and industrialization” (Riskin, 1991: 38-39). Mao (1975: 292) asserted that the formation of a centralised democracy was essential to the Party:

"If we are to make the party strong, we must practice democratic centralism to stimulate the initiative of the whole membership. There was more centralism during the period of reaction and civil war. In the new period, centralism 
should be closely linked with democracy. Let us apply democracy, and so give scope to initiatives that exist throughout the Party.”

If we interpret Mao's actions in light of Gramsci's theory, Mao's efforts to form alliances, displace conflict, and create harmonious conditions were consistent with attempts to create the environment for hegemonic control theorised by Gramsci. Mao's strategy, interpreted through Gramsci, included the state as an essential driver for the organisation of social and political life. The ruling party, after taking over power, would then mobilise Mao's ideological interests to influence the ideas of the masses and form a system of alliances. In order to obtain more support, the New Democracy was to rest on a broader social base, the workers, peasants, and petty bourgeoisie were to be one element of a national “united front” (Grasso et al., 2004: 145).

At this stage of Mao's leadership, Chinese capitalist businesses that existed prior to communist China, including private enterprises such as textile manufacturing companies that emerged following the First Opium War (1840), were maintained and considered as necessary to enhance the development of the economy. Meisner (1999: 59) translated Mao's statement for this strategy of building the new ideology:

“... [we] must utilize all elements of urban and rural capitalism that are beneficial and not harmful to the national economy... Our present policy is to 
control, not to eliminate, capitalism... under the leadership of the working class and the Communist party, the ultimate goal was to transform China from a 'new democracy' into a socialist and communist society.”

This idea of a New Democracy was embodied throughout China's economic practices. Riskin (1991: 40) translated archival documents that contained details of the economic strategy, Common Programme article 26-31, which was released in September 1949. This showed that the economy was to be divided into four sectors:

1. The state-owned sector: all enterprises vital to the economic stability [of] the country and to the people’s livelihood were to become unified and operated by the state.

2. The co-operative economy: regarded as semi-socialist in nature and would be accorded preferential treatment.

3. The private sector: to be 'encouraged and fostered' where beneficial to the national welfare.

4. The state-capitalist sector: an amorphous concept embodying the various means by which private production was subordinated to the state priorities. 
According to Mao, this early stage of political compromise was important in order to learn from the experiences of various classes. It was considered a necessary transitional period in order to move to a higher socialist phase (Huang, 2001). The ultimate goal of the CCP, however, was to establish a centralised socialist system in China, and follow the Soviet Union's model in developing a "centrally-planned” and “centrally-controlled" economy (Huang, 2001: 15). The primary concern in this system was to establish public ownership, which would allow a centralised policy to control economic activities (Ferrero, 2004). As such, planning activities would be required to reflect the state economic planning and decision making-processes. The state would maintain coercive power in making crucial decisions regarding the allocation of economic resources, such as land (Ferrero, 2004). Under this system, economic activities, from material production to the distribution of products, needed to be removed from the market and placed in the hands of the state (Yabuki, 1995). This centralised system was believed to be fundamental to the protection of workers (Ferrero, 2004).

When the government's ideology of the New Democracy came into effect in the early 1950s, the accounting system started to evolve, incorporating elements that reflected changes in the new socialist structure (Pan, 1952a, 1952b). Mao believed that the New Democracy movement would be the transition to a socialist society, and the accounting discipline in this early period of the New Democracy also maintained such a transitional 
feature as evidenced through debates and changing practices. Many of these debates were played out by accounting scholars, who strived to spread the ideology of the state by remodelling accounting practices. The ideas of these scholars were reflected in accounting textbooks as well as in professional journals, which were essential in educating the accounting profession, particularly during this early period of the new political regime. As theorised by Gramsci, the debates and competing ideas from accounting scholars provide evidence of the process whereby organic intellectuals counter traditional ideas in an effort to diffuse the political ideology of the state to the working class.

Traditional intellectuals. A group of accounting scholars emphasised the technical function of accounting through its form as a double-entry bookkeeping technique that resulted in financial statements such as the Income Statement and Balance Sheet. As identified in an accounting textbook - Fundamentals of Accounting published in 1950: “Accounting is a technology for managing economic activities” (Pan, 1950: 1). ${ }^{7}$ There was no discussion of political ideas in this book. Similar views were held by Guo and Liang (1951: 1) in Industrial Accounting that: "No matter how a company is organised and what the nature of the business is, accounting is nothing more than a study of dealing with the company's assets, liabilities and equity, and reporting the amount of changes to these accounts.” This book (Guo and Liang, 1951) was based on a Western 
accounting textbook - Industrial Accounting (Specthrie, 1942, New York: Prentice-Hall, Inc.). As noted, it was common practice for Western accounting textbooks to be translated and published in China during this period, for example, Cost Accounting (Lawrence 1946, New York: Prentice-Hall, Inc.); Elementary Cost Accounting (Schlatter, 1927, New York: Wiley \& Sons, Inc.). Along a similar line, another popular textbook Financial Accounting for State-Owned Enterprises (He, 1953) focused on the technical aspect of financial accounting without any discussion about political ideologies.

To illustrate the features of accounting in the New Democracy society, Pan (1952a: 1) explained that "the objectives of accounting shall be adjusted to accommodate the needs of the changing social economic system...hence, we need a different accounting system under the New Democracy society.” Because the New Democracy society still allowed the existence of private enterprises, the new accounting system described in this text included different accounting treatments for the four sectors in New Democracy: stateowned sector; co-operative sector; private sector and state-capitalist sector. Some specific features of this accounting system outlined in the textbook are described as follows: 
- The income statement of state-owned enterprises reflects the completion of central economic plans, rather than the earning capability as reflected in private sector accounting;

- Liabilities are not divided into current and non-current categories, instead they are reported in an order that is consistent with the central plan in the state-owned sector accounting method;

- Goodwill and intangible assets incurred due to the advantages of economic scale of substantial capital in private sectors are not recognised in state-owned sector accounting method (Pan and Yu, 1952).

Despite the differences, the fundamentals of accounting remained the same, but served different functions in different sectors. In practice, the balance sheet was based on a conventional accounting equation: "Asset = Liability + Equity" from 1949 to 1952 (Ministry of Finance 1953, 1955), which was the same practice prior to 1949.

These accounting scholars advocated a view of accounting which was inherited from the pre-communist revolution. As suggested by Gramsci, they are the kind of traditional intellectuals who closely followed their previous 'tradition and craft' and are considered to be independent of prevailing social interests and practice in the new political regime. Tao De was another influential accounting intellectual that can be considered 'traditional'. Tao (1951) published a paper in the New Accounting journal suggesting 
that accounting information was neutral and did not serve class interests. He stated that accounting is a "neutral technique, free of class struggle in nature, and it can only be seen as a combination of writing and numbers” (Tao, 1951, issue 4: 14). He further argued that socialist and capitalist accounting systems were the same in nature and that the only difference was in their relationship to production: in a socialist system profits belonged to the public, whereas in a capitalist system profits belonged to individuals (Tao, 1951). The fact that Tao's article was published by this top accounting journal was an important phenomenon because this action would have resulted in serious political sanctions if published in the later stages of Mao's rule when the idea of New Democracy was revoked.

Organic intellectuals. In contrast to the traditional intellectuals, the nature and functions of accounting were articulated very differently by another group of scholars at the time. In an accounting textbook, Wang and Liu (1952: 15) criticised the traditional view of accounting that "accounting meets the main task of the capitalism by serving the interest of the ruling class and helping capitalists accumulate more wealth.” Specifically they wrote:

"The competition in a capitalist economic system encourages capitalists to constantly looking for ways to sell their products and reduce their costs. Offering lower wages is one of the methods, but more importantly, it is 
about how to further exploit workers by making the production more efficient. The capitalists constantly observe the work of each worker to calculate certain quotas and use various methods to monitor the work in progress. So in capitalist societies, this technical function of accounting records is of high importance."

It was common among this group of organic scholars to begin their textbooks by stating the problems of traditional accounting in capitalism, and then proceeding to justify the ‘advantages’ of socialist accounting. For instance:

"In a capitalist economic system, the calculation of cost is to help the bourgeoisie make more profits. This is achieved through reducing production quality, extending working hours of workers, and lowering wages so that capitalists could extract more surplus value. Cost accounting is an effective tool for capitalists to achieve this aim. And because of the inherent weakness of the capitalist economic system where the production and consumption are detached, it is impossible to have correct costing information.

However, under the socialist economic system, all economic activities are centrally planned to maximise the interests of all people and the nation. Cost accounting can, therefore, not only obtain accurate and timely information, but also reflect the problems in industrial management to minimise waste, improve labour productivity, reduce costs and gradually accumulate state funds to improve the lives of working people” (Zheng, 1952: 1). 
Another feature of this discourse was the use of political ideas, in particular via quotes from political leaders, in theorising accounting in a socialist context. Wang and Liu (1952) praised the accounting system under the new regime with reference to Mao's remark on the conflict between socialism and capitalism and the unquestioned triumphs of socialism:

"What is old accounting? And what is new accounting? This can be interpreted in two ways. Firstly, under the current international environment, Chairman Mao said: “it is about the struggle between capitalism and socialism where capitalism is in downward decline and socialism is in upward growth.” Therefore, the capitalist accounting, which is developed in the declining capitalist countries to serve the interest of the bourgeoisie, is the old accounting. The socialist accounting which is developed in the growing socialist countries, and based on Marxism-Leninism to serve the interest of the working people, is the new accounting. Secondly, under the domestic environment, the accounting system which was adopted in the semi-colonial, semi-feudal society was based on capitalist accounting and it served the reactionary ruling classes - imperialist, feudal landlord class and the bureaucrat-capitalist. It is the old accounting. Since the birth of new China, the nature of state power and socio-economic relations has changed. Accounting is no longer serving the reactionary ruling class, but instead serves the working people, particularly the workers and peasants. This 
accounting in new democracy is part of a socialist accounting category, so it is the new accounting” (Wang and Liu, 1952: 1).

Statements of Marx, Stalin and Lenin were frequently referenced to illustrate the purpose of accounting. For instance:

"Comrade Stalin instructed us: 'in a capitalist system, the national power belongs to the capitalist class, production tools are controlled in the hands of exploiters; the working class is exploited as they are not working for themselves, but for the capitalists.' Because the private property ownership is the basis of the capitalist system, and the ultimate purpose of production is to maximise the profits for capitalists, the capitalist accounting, therefore, focuses only on a single entity and follows solely the instructions of the owners of capital” (Wang and Liu, 1954: 6).

"Lenin once said: 'the law of keeping trade secrets is not to meet the production needs, but to cover speculative and unfair profit-making. It helps cover up blatant fraudulent behaviour in capitalist economic activities.' Along a similar line, capitalists manipulate accounting information to hide the true profits made and hence their exploitation over working class. They also forge accounting information as a means to enhance competitiveness. Therefore, the accounting information in a capitalist system is not true, but deceptive; it is not open but secretive" (Wang and Liu, 1954: 7). 
The traditional views based on Western accounting systems were challenged by this group of scholars, organic intellectuals following Gramsci's term. They became increasingly concerned with a more emancipated accounting system and its role in class struggles. The journal, New Accounting, made public discussions and debates that reflected the shifting political ideology during this period. Xin and Huang (1951), for example, published a paper in New Accounting and argued against the basic accounting equation "Assets - Liabilities = Equity" because of its derivation from capitalist ideology. Xin and Huang (1951) also analysed the capitalist-based accounting equation "profit $=$ revenue - expenses" to show how the proletariat was marginalised as an expense to serve the profit-making motives of the bourgeoisie. Following Marxist principles, Xin and Huang (1951) argued that the profit should belong to the labour forces as they were the ones responsible for its production.

For the organic intellectuals, Tao's (1951) view that accounting is a pure technology without a class feature was unacceptable and intensely criticised in New Accounting. The editorial board published six papers that were said to be representative of the readers’ opinions against Tao’s (1951) work. Jia (1951), for example, rejected Tao’s views outright, arguing that the concept of capital should not exist in socialist accounting systems. Ren (1951), in the vein of Xin and Huang (1951), claimed that capitalist accounting serves the interests of the bourgeoisie by disguising exploitative 
relationships between the labour force and profit makers. Xin and Huang's (1951) work attracted significant attention within the accounting community, and the class nature of accounting proposed in their original study was influential until 1980s (see, for example, Ge, 1978; He, 1979, 1980; Ye, 1979; Yang and Yan, 1980; Lou and Shi, 1980; Li, 1980; Ge and Huang, 1980; Yu 1980).

This type of contest between traditional and organic accounting intellectuals can be described, in Gramsci's terms, as the "struggle to assimilate and conquer 'ideologically' the traditional intellectuals” (Simon, 1982: 95) during the construction of hegemony. This (re)theorisation of economic production and the function of accounting helped to re-shape the understanding of accounting at a societal level. As demonstrated in the above passages, by encouraging consideration of the purpose of economic production and the role of the labour force within it, the organic intellectuals shifted the orientation of accounting away from traditional notions of profit-making and towards the use of accounting as a representation of economic activity according to a different social goal.

The process of creating intellectual agreement is, according to Gramsci (1971) part of the profound moral and intellectual reform that is long, difficult, but fundamental if a class is to raise itself over another class to lead the nation. The success of constructing consensus among accounting intellectuals, in the context of China's accounting practice, 
was also demonstrated in another major ideological shift - the Leaning to One Side movement during the period.

\section{Leaning to One Side}

The idea of New Democracy was revoked in 1954 when Mao urged the CCP and the public to adopt a policy of Leaning to One Side (Saich, 2004). This policy outlined Mao’s strategy of adopting the socio-economic practices of the Soviet Union. Mao regarded the Soviet Union as the heir to Marxism, and had successfully applied Marxist models in establishing urban industries, developing managements systems, employing a strategy of planning economy, and providing for scientific and technical education (Riskin, 1991). In particular, Mao emphasised the importance of learning techniques that would lead to greater centralisation (Saich, 2004). In other words, the adoption of the Soviet model required learning Soviet management systems and also creating a Soviet-style society. During the 1950s, more than ten thousand Soviet experts worked in China, and at least eighty thousand Chinese scholars were trained in the Soviet Union (Gittings, 2005). Gittings (2005: 25) cited the words of the head of the Chinese Publications Administration, that 
"without the moral and material assistance of the Soviet Union, the nationwide victory of the Chinese revolution would have been inconceivable, so it is not surprising that there is an upsurge of interest all over the country to study the Soviet Union and her advanced socialist experience”.

In the accounting discipline, the most fundamental accounting change was the replacement of the basic accounting equation from "Asset = Liability + Equity" to “Applications of Funds = Sources of funds” (Huang, 2001). Wang and Liu (1954: 25) argued that the equation "Applications of Funds = Sources of Funds" reflected the organic process required to move to the socialist economic system. The state arranged the production for every work unit, and the plan of the state embodied the plan of each unit (Wang and Liu, 1954). In the process of completing tasks, every work unit was allocated some funds from the state, and the profit from production was collected and controlled by the state. In this way, only two elements were necessary to show this relationship in the accounting equation: the application of funds and the sources of funds. The application of funds described how funds were used in the productive processes, such as for the purchase of equipment. Sources of funds describe how funds have been obtained, for example from government-granted funds or seasonal loans. The application and sources of funds were required to be equal at all times. The term 'fund' in the equation was similar in nature to the term 'capital' however the term "fund" was used to differentiate it for the socialist economy (Huang, 2001). 
This new accounting model was integral to the centralised socio-economic planning model that Mao intended to adopt from the Soviet Union. Two speeches made by Makarov (1951, 1952), one of the Soviet Union’s accounting experts, were influential to Chinese accounting practice at the time. In his first speech, Makarov (1951) systematically introduced the socialist accounting system. He stated that the socialist economy was based on a plan, and that the entire plan was for the development of a unified national system. Thus, accounting systems needed to change to reflect the new focus of the national economy, namely socialist economic production. The purpose of accounting was to supervise and guide the plan, check the progress of the plan, and ensure the plan could be completed in time (Makarov, 1951). Makarov (1951) pointed out that the accounting equation "Asset $=$ Liability + Equity" was not suitable in a socialist economy as it reflects information relating only to individual enterprises.

The translation of Western accounting textbooks ceased. Those published during the period were either directly translated from or based on Soviet Union's accounting textbooks, for example: New Accounting (Wang and Liu, 1954); Industrial Accounting (Renmin University, 1956); Industrial Accounting (Xu, 1957). In line with the position taken by organic intellectuals in the previous period, these books all highlighted the 'evil' nature of capitalism and how it hid exploitation. These texts also stressed that the 
socialist accounting method was a powerful weapon for working people in the building of socialism. The following quote represents a typical example of such discourse:

“[In capitalism,] workers are in a position to be exploited and oppressed because all the fruits of their labour are grabbed by capitalists. Also they are not voluntary in the production, but are forced to endure the brutal capitalist exploitation under the threats of hunger and unemployment. Capitalist accounting for labour and wages, in essence, is to strengthen the exploitation of workers and to maximise profits from surplus value.

In our socialist country, production has become a glorious career for every member of society who has the ability to work. In the state-owned enterprises, labour and the possession of production means are unified that workers are the masters and they work to create a beautiful life of socialism” (Renmin University 1956: 23).

The journal, New Accounting, was discontinued and Industry Accounting replaced the role of this journal in 1952. By 1955, in its first issue for the year, the editorial section of Industry Accounting displayed a much firmer attitude than in previous years: "it is undeniable that the bourgeois, reactionary ideological perspectives still influence the accounting profession. This influence must be quickly eliminated, and this is one of the main tasks of our journal." It also devoted significant space to the critique of the ‘incorrect' political position adopted in some accounting books published before 1954 . 
Similar to the criticisms directed towards Tao De in the New Democracy period, another accounting academic, Wang Danru, became the target of renewed anger. For instance:

"In the book - Public Accounting [written by Wang, Danru]... it is a serious mistake that the book only focuses on commercial enterprises, i.e. the business circulation of commodities, rather than production. This reinforces the interest of capitalists who claim that the expansion of capital is not due to the labour work in production, but the circulation of commodities. The reactionary nature of this theory in accounting is obvious.

...Recognising government funds as liabilities signifies to readers that the funds are the debts of enterprises. This view is wrong because state-owned enterprises belong to everyone in our socialist and democratic country, government funds therefore are the source of funds, but not liabilities for enterprises” (Huang et. al., 1955a: 26).

A focus of the criticism centred on Wang's view that accounting is a recording tool, a purely technical craft that is irrelevant to class struggles and politics. An interesting example is one of the discussion questions in Wang's textbook:

"Question: Please discuss why we cannot learn accounting system from capitalist countries?

Answer: The development of state-owned enterprises in our country will be rapidly increasing from now on ... to ensure the evolution of the New 
Democracy to a socialist economy. Therefore, we should take the statedowned enterprises accounting as the primary learning objective and learn socialist accounting theory ...” (Huang et al., 1955b, issue 9: 25).

Although the answer to the question appears reasonable, critics argued that Wang did not show the advanced and the scientific nature of socialist accounting, and did not reveal the deceptive nature of the capitalist accounting (Huang et al., 1955b). In other words, Wang was accused of not sufficiently criticising the capitalist system in his suggested answer (Huang et al., 1955b). In response to these criticisms, the textbook publishers issued a public apology in the Industry Accounting journal, stating that they should not be influenced by 'evil' capitalist accounting practices, and that they would try their best to help to contribute to the socialist transformation in a short time period (Lixin Accounting Publishing house, 1955). The journal also published readers’ letters complaining that they had been negatively influenced by the contents of Wang's book leading to substantial losses in their accounting work (letters cited in Lixin Accounting Publishing house, 1955). Readers expressed their wish that the reactionary thoughts included in Wang's texts be eliminated from all future accounting books (letters cited in Lixin Accounting Publishing House, 1955).

As discussed previously, to achieve a complete transition to a new social system, a transformation of the political ideology is required to enable dismantling of the 
capitalist class and its replacement with the working class (Simon, 1982). This process is "inseparable from changes in the outlook and consciousness of those who are involved or, as Gramsci put it, from intellectual and moral reform” (Simon, 1982: 45). As has shown in this section, this process is manifested through the battle between traditional and organic accounting intellectuals to build up a new social consciousness for socialist society by making sense of accounting systems and then diffusing this accounting knowledge through its widespread practice. Considering Gramsci's theory in light of these developments in Chinese accounting practice, it is evident that accounting scholars were influential in weakening the capitalist accounting attitudes and diffusing the political ideologies of New Democracy, and then continuing their role as China moved to the next stage of social and economic reform through the Leaning to One side movement. In doing so, the organic accounting intellectuals made the connection between political ideology and accounting practices, contributing to the construction of ideological consensus for the interest of working class during this early social transition in China.

\section{Summary and conclusion}

By connecting accounting to its broader context, researchers have been able to demonstrate the social and political nature of accounting (Dillard, 1991; Funnell, 1996; 
Baker and Bettner, 1997; West, 1998; Laughlin, 2004; Tinker, 2005; Cortese and Irvine, 2010; Zhang et al., 2012). It has been well documented in the literature that accounting does more than just presenting economic 'facts'; rather, it shapes its surrounding environments influencing decisions related to economics, society, politics, legitimacy and organisations in a much deeper way (West, 1998). This paper contributes to the literature by further investigating this socio-political nature of accounting by examining accounting change during the transitional period of Chinese history. The paper uses Gramsci's theory of hegemony to demonstrate the role of accounting in ideological diffusions for sustaining political dominance during the period of 1949-1957, a period in China’s history which has so far been largely unexamined.

The relationships and struggles between organic and traditional intellectuals that Gramsci has theorised are examined in this historical context, highlighting the tensions that pervaded China at the time. Gramsci argues that civil consent, rather than coercive force, is a predominant source of power for the establishment and maintenance of the state. Political dominance is obtained by establishing and diffusing a hegemonic culture so that the ideology of ruling class is perceived as common sense among people. A hegemonic class, therefore, becomes that which is able to create and maintain a network of alliances in a society through moral and intellectual struggles. This consensus- 
forming is both manifested and facilitated through a process whereby organic intellectuals achieve dominance over traditional thought.

By analysing the archival documents of accounting textbooks and journal articles published from 1949 to 1957 in China, this paper offers examples that demonstrate the function of accounting as part of a moral and intellectual force in sustaining class power. Specifically, two political ideologies, namely New Democracy and Leaning to One Side, have been identified as the ideological contexts in which accounting evolved during the period of hegemonic transition. Whilst traditional accounting intellectuals defended the technical view of accounting, organic intellectuals embedded their arguments on prevailing political ideas, re-orienting the purpose of accounting to protect the interest of working class and facilitate the implementation of central planning. Changes in the accounting system, revealed by this paper, are seen to result from the cohesive force of accounting intellectuals who were integral in mobilising intellectual and moral cultures through knowledge diffusion and education. This ideological diffusion forms part of the institutional apparatus that consolidated the political hegemony of the CCP during the transitional period of 1949-1957 in China. 
Acknowledgments: We gratefully acknowledge the feedback and support of Professor Garry Carnegie, participants of the Seventh Asia Pacific Interdisciplinary Research in Accounting Conference, and academics in the Discipline of Accounting at the University of Wollongong.

\section{Notes}

${ }^{1}$ The socio-political developments during these periods are well documented in many other Chinese history studies, such as Twitchett and Fairbank (1991), Grasso et al., (2004).

${ }^{2}$ Given our focus is on intellectuals, it is worth mentioning this movement as a contrast to the hegemonic approach during 1949 to 1957 . The Anti-Rightist movement mainly targeted those intellectuals who appeared to be in favour of the capitalist mode of production and critical towards some of the socialist government's policies. The number of intellectuals who were politically persecuted during the movement is estimated to be 550,000 (Chen, 2007).

${ }^{3}$ It should be noted that the conflicts referred to here are "minimal" only when compared to later stages in the Maoist regime. The history of China between 1949 (the establishment of People's Republic) to 1978 (the commencement of the economic reform) was strikingly chaotic in terms of the social conflicts that resulted in the death of millions of civilian people during those political campaigns. While "minimal" in the context of China's history, the period of this study, 1949-1957, would still be considered chaotic compared to other peaceful times.

${ }^{4}$ These journal articles were photocopied from the Chinese National Library in Beijing.

${ }^{5}$ Lixin Accounting Publishing House was the first publisher of accounting textbooks in China and was founded in 1941. It has been very influential among Chinese accounting communities. Scanned copies of these textbooks are available online from http://www.szdnet.org.cn/.

${ }^{6}$ Gramsci's ideas were fragments scattered throughout his 2,848 pages (packed in 33) notebooks. They were not intended to be published or be read like a theory book. Hence, many of his concepts were neither defined with precision nor organised in a coherent form. Various versions of English translations also add extra complications for researchers to comprehend many of his ideas, as well as making direct references to them. Hence, this section, except where specific references are made, has been developed based on a secondary source - a book by Roger Simon (1982) which provides a comprehensive and coherent overview of Gramsci's theory making it more accessible for researchers.

${ }^{7}$ The author - Pan, Xulun - was a prominent accounting scholar who had been writing accounting textbooks for schools and universities in China since 1930. 


\section{References}

Aiken M and Lu W (1993) Chinese Government Accounting: Historical Perspective and Current Practice. The British Accounting Review 25(2): 109-129.

Alawattage C and Wickramasinghe D (2008) Appearance of Accounting in a Political Hegemony. Critical Perspectives on Accounting 19(3): 293-339.

Andrew J and Cortese C (2013) Free market environmentalism and the neoliberal project: The case of the Climate Disclosure Standards Board. Critical Perspectives on Accounting: 397-409.

Baker CR and Bettner MS (1997) Interpretive and Critical Research in Accounting: A Commentary on its Absence from Mainstream Accounting Research. Critical Perspectives on Accounting 8(4): 293-293.

Bates TR (1975) Gramsci and the Theory of Hegemony. Journal of the History of Ideas 36(2): 351-366.

Bing X (1998) Institutional Factors Influencing China's Accounting Reforms and Standards. Accounting Horizons 12(2): 105-119.

Chan L and Rotenberg W (1999) Accounting, Accounting Education, and Economic Reform in the People's Republic of China. International Studies of Management and Organization 29(3): 37-53.

Chen S (1998) The Rise and Fall of Debit-Credit Bookkeeping in China: History and Analysis. The Accounting Historians Journal 25(1): 73-91.

Chen Z (2007) The "Active Rightists" of 1957 and Their Legacy: "Right-wing Intellectuals,” Revisionists, and Rights Defenders. China Perspectives_2007(4): 39-50.

Chua WF and Poullaos C (1993) Rethinking the Profession-State Dynamic: The Case of the Victorian Charter Attempt, 1885-1906. Accounting, Organizations and Society 18(7): 691-728.

Chua WF and Poullaos C (1998) The Dynamics of "Closure" Amidst the Construction of Market, Profession, Empire and Nationhood: An Historical Analysis of an Australian 
Accounting Association, 1886-1903. Accounting, Organizations and Society 23(2): 155-187.

Cooper C (1995) Ideology, Hegemony and Accounting Discourse: A Case Study of the National Union of Journalists. Critical Perspectives on Accounting 6(3): 175-209.

Cortese C (2011) Standardizing Oil and Gas Accounting in the Us in the 1970s: Insights from the Perspective of Regulatory Capture. Accounting History 16(4): 403-421.

Cortese C and Irvine H. (2010) Investigating international accounting standard setting: The black box of IFRS 6. Research in Accounting Regulation 22: 87-95.

Dillard JF. (1991) Accounting as a Critical Social Science. Accounting, Auditing \& Accountability Journal 4(1): 8-28.

Evans L (2010) Observations on the changing language of accounting. Accounting History 15: 439-462.

Ezzamel M, Xiao JZ and Pan A (2007) Political Ideology and Accounting Regulation in China. Accounting, Organizations and Society 32(7-8): 669-700.

Fairbank JK and Feuerwerker A (1986) The Cambridge History of China. Cambridge UK: Cambridge University Press.

Femia J (1975) Hegemony and Consciousness in the Thought of Antonio Gramsci. Political Studies 23(1): 29-48.

Ferguson J, Collison D, Power D, et al. (2009) Constructing Meaning in the Service of Power: An Analysis of the Typical Modes of Ideology in Accounting Textbooks Critical Perspectives on Accounting 20(8): 896-909.

Ferrero M (2004) A Ratuibak Theory of Socialist Public Ownership. Rationality and Society 16(4): 371-397.

Fu P (1971) Governmental Accounting in China During the Chou Dynasty (1122 B.C.256 B.C.). Journal of Accounting Research 9(1): 40-51.

Funnell W (1996) Preserving History in Accounting: Seeking Common Ground Between "New" And "Old" Accounting History. Accounting, Auditing \& Accountability Journal 9(4): 38-64. 
Funnell W (1998) Accounting in the Service of the Holocaust. Critical Perspectives on Accounting 9(4): 435-464.

Gao S and Handley-Schachler M (2003) The Influences of Confucianism, Feng Shui and Buddhism in Chinese Accounting History. Accounting History Review 13(1): 4168.

Ge J and Huang Z (1980) Lun jing ji he suan zhi yu kuai ji [Chinese]. Accounting Research 1: 20-30.

Ge J and Liu F (1999) Xin zhong guo kuai ji li lun yan jiu 50 nian hui gu [Chinese]. Accounting Research 10: 7-14.

Ge J (1978) Bi xu ti jie dai ji zhang fa hui fu ming yu - ping suo wei zi ben zhu yi de ji zhang fang fa [Chinese]. Economic Issues in China 4: 1-10.

Gittings J (2005) The Changing Face of China. New York: Oxford University Press Inc.

Goddard A (2002) Development of the Accounting Profession and Practices in the Public Sector-a Hegemonic Analysis. Accounting, Auditing \& Accountability Journal 15(5): 655-688.

Goddard A (2005) Reform as Regulation-Accounting, Governance and Accountability in Uk Local Government. Journal of Accounting \& Organizational Change 1(1): 27-44.

Graham LE and Li C (1997) Cultural and Economic Influences on Current Accounting Standards in the People's Republic of China. The International Journal of Accounting 32(3): 247-278.

Gramsci A (1971) Selections from the Prison Notebooks of Antonio Gramsci. New York: International Publishers.

Grasso J, Corrin J and Kort M (2004) Modernization and Revolution in China: From the Opium Wars to World Power, New York: M.E. Sharp.

Guo S and Liang Q (1951) Gong ye kuai ji [Chinese], Shanghai: Lixin Accounting Publishing House. 
He G (1953) Guo ying qi ye cai wu kuai ji he suan [Chinese], Beijing: Industry and Business Publisher.

He N (1979) ji zhang fang fa mei you jie ji xing [Chinese]. Finance and Accounting: 2: 20-23.

He N (1980) zai lun ji zhang fang fa mei you jie ji xing [Chinese]. Shanghai Accounitng 2: 68-73.

Huang A (2001) Accounting in China in Transition, 1949-2000. River Edge: World Scientifc.

Huang S, Yan D and He N (1955a) Ping Wang Danru he Zhang Peiyi bian zhu de [da zhong kuai ji] yi shu [Chinese]. Industry Accounting 2: 26-28.

Huang S, Yan D and He N (1955b) Dui 1954 nian li xin kuai ji tu shu yong pin chu ban she de ji ben you guan kuai ji he suan shu ji de yi jian [Chinese]. Industry Accounting 9: 25-28.

Ji X, and Lu W (2013) The evolution of bookkeeping methods in China: a Darwinist analysis of developments during the twentieth-century. Accounting History 18(3): 317341.

Jia G (1951) Pi pan Tao De de zen yang jian li xin zhong guo kuai ji li lun ji chu [Chinese]. New Accounting 7: 16-17.

Josiah J, Burton B, Gallhofer S, et al. (2010) Accounting for Privatisation in Africa? Reflections from a Critical Interdisciplinary Perspective. Critical Perspectives on Accounting 21(5): 374-389.

Landau I (2008) Law and Civil Society in Cambodia and Vietnam: A Gramscian Perspective. Journal of Contemporary Asia 38(2): 244-258.

Laughlin R (2004) Putting the Record Straight: A Critique of 'Methodology Choices and the Construction of Facts: Some Implications from the Sociology of Knowledge Critical Perspectives on Accounting 15(2): 261-277.

Lawrence WB (1946) Cost Accounting, New York: Prentice-Hall, Inc. 
Lehman C and Tinker T (1987) The "Real" Cultural Significance of Accounts. Accounting, Organizations and Society 12(5): 503-522.

Li T (1980) The Nature, Position and Function of Accounting. Accounting Research 02: 35-40.

Lin ZJ and Chen F (2000) Asian Financial Crisis and Accounting Reforms in China. Managerial Finance 26(5): 63-79.

Lin Z (2003) Chinese Bookkeeping Systems: A Study of Accounting Adaptation and Change. Accounting, Business and Financial History13(1): 83-98.

Lixin accounting Publishing house (1955) Li xin tu shu yong pin chu ban she biao shi jie shou ben kan pi ping [Chinese]. Industry Accounting 8: 36-37.

Llewellyn S and Northcott D (2005) The Average Hospital. Accounting, Organizations and Society 30(6): 555-583.

Lou E and Shi C (1980) Conceive of Establishing China's Accounting Theoretical System [Chinese]. Journal of Finance and Economics 4: 27-34.

Lu W and Aiken M (2003) Accounting History: Chinese Contributions and Challenges. Accounting, Business and Financial History 13(1): 1-3.

Makarov (1951) She hui zhu yi kuai ji de shi wu [Chinese]. New Accounting 6: 1.

Makarov (1952) Lun kuai ji he suan de jie ji xing [Chinese]. Industry Accounting 4: 1-7.

Mao T (1975) Selected Works of Mao Tse-Tung, Peking: Foreign Language Express.

Meisner M (1999) Mao's China and After, New York: The free press.

Merino BD, Mayper AG and Tolleson TD (2010) Neoliberalism, deregulation and Sarbanes-Oxley: The legitimation of a failed corporate governance model. Accounting, Auditing \& Accountability Journal 23: 774-792.

Miles L and Croucher R (2013) Gramsci, Counter-Hegemony and Labour Union-Civil Society Organisation Coalitions in Malaysia. Journal of Contemporary Asia 43(3): 413-427. 
Ministry of Finance (1953) Zhong yang cai zheng fa gui hui bian: 1951-1952 [Chinese], Beijing: People's Government Ministry of Finance.

Ministry of Finance (1955) Zhong yang cai zheng fa gui hui bian: 1954 [Chinese], Beijing: People's Republic of China Ministry of Finance.

Moerman L and Van Der LS. (2007) Pursuing Shareholder Value: The Rhetoric of James Hardie. Accounting Forum 31(4): 354-369.

O'Dwyer B (2005) The Construction of a Social Account: A Case Study in an Overseas Aid Agency. Accounting, Organizations and Society 30(3): 279-296.

Pan X (1950) Ji chu kuai ji xue [Chinese], Shanghai: Lixin Accounting Publishing House.

Pan X (1952a) Kuai ji xue jiao cheng 1 [Chinese]. Shanghai: Lixin Accounting Publishing House.

Pan X (1952b) Kuai ji xue jiao cheng 2 [Chinese]. Shanghai: Lixin Accounting Publishing House.

Pan X and Yu W (1952) Guo ying qi ye kuai ji gai yao [Chinese]. Shanghai: Lixin Accounting Publishing House.

Ren C (1951) Pi pan Tao De de zen yang jian li she hui zhu yi li lun jian she ji chu [Chinese]. New Accounting 7: 17-18.

Renmin University (1956) Gong ye kuai ji [Chinese], Beijing: Renmin University Publishing Hourse.

Richardson AJ (1987) Accounting as a Legitimating Institution. Accounting, Organizations and Society 12 (4): 341-355.

Richardson AJ (1989) Corporatism and Intraprofessional Hegemony: A Study of Regulation and Internal Social Order. Accounting, Organizations and Society 14(5): 415-431.

Riskin C (1991) China's Political Economy: The Quest for Development since 1949, New York: Oxford University Press. 
Rodrigues LL and Craig R (2009) Teachers as servants of state ideology: Sousa and Sales, Portuguese School of Commerce, 1759-1784. Critical Perspectives on Accounting 20: 379-398.

Saich T (2004) Governance and Politics of China, New York: Palgrave Macmillan.

Schlatter CF. (1927) Cost Accounting, New York: Wiley \& Sons, Inc.

Sikka P and Dunn J (1998) The Emergence of the Uk Auditor Resignation Legislation. Accounting History 3(1): 95-113.

Sikka P and Willmott H (1995) The Power of "Independence": Defending and Extending the Jurisdiction of Accounting in the United Kingdom. Accounting, Organizations and Society 20(6): 547-581.

Sikka P (1995) Illuminating the State-Profession Relationship: Accountants Acting as Department of Trade and Industry Investigators. Critical Perspectives on Accounting 6(4): 341-369.

Sikka P (2004) Some Questions About the Governance of Auditing Firms. International Journal of Disclosure and Governance 1(2): 186-200.

Sim SF (2006) Hegemonic Authoritarianism and Singapore: Economics, Ideology and the Asian Economic Crisis. Journal of Contemporary Asia 36(2): 143-159.

Simon R (1982) Gramsci's Political Thought. London: Lawrence and Wishart.

Solas C and Ayhan S (2007) The Historical Evolution of Accounting in China: The Effects of Culture. Spanish Journal of Accounting History: 146-173.

Specthrie SW (1942) Industrial Accounting, New York: Prentice-Hall Inc.

Spence C (2009) Social Accounting's Emancipatory Potential: A Gramscian Critique. Critical Perspectives on Accounting 20(2): 205-227.

Tang Q and Lau A (2000) Accounting Reforms in China: A Transition from State Plan and Control-Oriented System to Capital Market-Oriented System. Managerial Finance 26(5): 80-99. 
Tang Y (1997) The Recent Accounting Development and Internationalization of Accounting Education in China. Issues in Accounting Education 12(1): 219-229.

Tao D (1951) Zen yang jian li xin zhong guo kuai ji li lun ji chu - du hou [Chinese]. New accounting 4: 14-15.

Tinker T (2005) The Withering of Criticism: A Review of Professional, Foucauldian, Ethnographic, and Epistemic Studies in Accounting. Accounting, Auditing \& Accountability Journal 18(1): 100-135.

Twitchett D and Fairbank J (1991) Revolutions within the Chinese Revolution 19661982. The Cambridge History of China. Cambridge: Cambridge University Press.

Wang F and Liu W (1952) Xin kuai ji xue jiao cheng di yi ce [Chinese], Shanghai: Lixin Accounting Publishing House.

Wang P and Liu W (1954) Xin kuai ji xue [Chinese], Shanghai: Lixin Accounting Publishing House.

West BP (1996) The Professionalisation of Accounting: A Review of Recent Historical Research and Its Implications. Accounting History 1(1): 77-102.

West BP (1998) Exploring Professional Knowledge: The Case of Accounting. Journal of Sociology 34 (1): 1-22.

West B and Carnegie GD. (2010) Accounting's chaotic margins: Financial reporting of the library collections of Australia's public universities, 2002-2006. Accounting, Auditing \& Accountability Journal 23: 201-228.

Winkle GM, Fenwick H and Chen XZ (1994) Accounting Standards in the People's Republic of China: Responding to Economic Reforms. Accounting Horizons 8(3): 4857.

Xin Z and Huang S (1951) Zen yang jian li xin zhong guo kuai ji li lun ji chu [Chinese]. New Accounting 1(1): 12-16.

Xu K (1957) Gong ye cheng ben kuai ji jiao cheng [Chinese], Lixin Accounting Publishing House: Shanghai. 
Yabuki S (1995) China's New Political Economy: The Giant Awakes. Boulder: Sososha Ltd.

Yang J and Yan D (1980) Kai zhan wo guo kuai ji li lun yan jiu de ji dian yi jian - jian lun kuai ji xue de ke xue shu xing [Chinese]. Accounting Research 1(1): 2-10.

Ye M (1979) Ji zhang you mei you jie ji xing ? Yu He Nanxuan tong zhi shang cuo [Chinese]. Accounting and Finance Communication 8: 36-38.

Yee H (2009) The Re-Emergence of the Public Accounting Profession in China: A Hegemonic Analysis. Critical Perspectives on Accounting 20(1): 71-92.

Yee H (2012) Analyzing the State-Accounting Profession Dynamic: Some Insights from the Professionalization Experience in China. Accounting, Organizations and Society 37(6): 426-444.

You J and Luo S (2009) Accounting Internationalization and Value Relevance of Accounting Earnings in China. Frontiers of Business Research in China 3(2): 171-189.

Yu X (1980) Yao cong fa zhan de guan dian kan kuai ji xue de ke xue shu xing [Chinese]. Economic issues in China 5: 46-47.

Zhang Y and Andrew J (2010) Land in China: Re-Considering Comparability in Financial Reporting. Australasian Accounting Business and Finance Journal 4(1): 5375.

Zhang Y, Andrew J and Rudkin K (2012) Accounting as an Instrument of Neoliberalisation?: Exploring the Adoption of Fair Value Accounting in China. Accounting, Auditing \& Accountability Journal 25(8): 1266-1289.

Zheng Y (1952) Gong ye cheng ben kuai ji jiao cheng [Chinese], Shanghai: Lixin Accounting Publishing House. 